\title{
STUDI TENTANG PERSAMAAN FUZZY
}

\author{
Elva Ravita Sari dan Evawati Alisah \\ Jurusan Matematika Fakultas Sains dan Teknologi Universitas Islam Negeri \\ Maulana Malik Ibrahim Malang \\ e-mail: mbemvie@gmail.com
}

\begin{abstract}
ABSTRAK
Bilangan fuzzy merupakan konsep perluasan dari bilangan tegas. Misalkan A adalah himpunan fuzzy dalam semesta himpunan semua bilangan riil $\mathrm{R}$, maka A disebut bilangan fuzzy jika memenuhi empat sifat diantaranya yaitu: himpunan fuzzy normal, mempunyai support S(A) yang terbatas, semua $A_{\alpha}$ merupakan interval tertutup untuk semua $\alpha \in[0,1]$ dalam $R$, dan konveks. Operasi aritmetika pada bilangan fuzzy dilakukan dengan memanfaatkan $\alpha$-cut yang berbentuk interval tertutup dengan menggunakan fungsi keanggotaan bentuk segitiga, karena bentuk ini sederhana dan sudah memenuhi syarat keanggotaan bilangan fuzzy, dan sudah mewakili dari representasi fungsi keanggotaan bentuk yang lainnya.

Persamaan fuzzy adalah kombinasi dari bilangan fuzzy dan operasi aritmetika fuzzy. Misalkan A dan B adalah bilangan fuzzy pada semesta $\mathrm{R}$ dengan fungsi keanggotaan masing-masing $\mu_{\mathrm{A}}$ dan $\mu_{\mathrm{B}}$ * adalah empat operasi aritmetika dasar pada $\mathrm{R}$, maka operasi $\mathrm{A} * \mathrm{~B}$ yaitu $(\mathrm{A} * \mathrm{~B})_{\alpha}=\mathrm{A}_{\alpha} * \mathrm{~B}_{\alpha}$. Selama $(\mathrm{A} * \mathrm{~B})_{\alpha}$ adalah interval tertutup untuk setiap $\alpha \in[0,1]$, dan $A$ dan $B$ adalah bilangan fuzzy, maka $A * B$ juga bilangan fuzzy. Prosedur penyelesaian persamaan fuzzy yaitu dengan merepresentasikan bilangan fuzzy dalam bentuk $\alpha$-cut menggunakan fungsi keanggotaan segitiga. Kemudian mengoperasikannya menggunakan operasi aritmetika pada bilangan fuzzy. Penentuan hasil operasi aritmetika pada persamaan fuzzy dilakukan dengan merepresentasikan ulang bilangan fuzzy tersebut dengan $\alpha$-cut, sehingga didapatkan bilangan fuzzy baru sebagai hasil penyelesaian dari persamaan fuzzy.

Pada skripsi ini hanya memfokuskan pokok bahasan pada persamaan fuzzy. Maka dari itu, disarankan kepada pembaca untuk mengkaji lebih lanjut tentang bentuk aljabar klasik yang lainnya yaitu pertidaksamaan linier yang dikembangkan menjadi pertaksamaan fuzzy. Dapat juga mengkaji lebih lanjut tentang sistem persamaan fuzzy.
\end{abstract}

Kata Kunci: Bilangan Fuzzy, Operasi Aritmetika, dan Persamaan Fuzzy.

\section{PENDAHULUAN}

Aljabar merupakan cabang dari matematika yang tergolong klasik, tetapi dalam perkembangannya memiliki beberapa keunggulan terutama dalam aplikasinya dengan ilmu-ilmu eksak lainnya. Aljabar dasar mencatat sifat-sifat operasi bilangan riil, menggunakan simbol sebagai pengganti untuk menandakan konstanta dan variabel, dan mempelajari aturan tentang ungkapan dan persamaan matematis yang melibatkan simbol-simbol.

Persamaan matematis tersebut seperti: $(a)$ $2 x-6=4-3 x, \quad(b) y^{2}+3 y=4, \quad$ dan $(c)$ $2 x+3 y=4 x y+1$. Suatu persamaan disebut persamaan linier dalam suatu variabel jika pangkat tertinggi dari variabel dalam persamaan tersebut adalah 1 . Suatu persamaan disebut persamaan kuadrat dalam variabel jika pangkat tertinggi dari variabel tersebut adalah 2 . Persamaan (a) adalah persamaan linier dalam satu variabel, persamaan $(b)$ adalah persamaan kuadrat dalam satu variabel, dan persamaan $(c)$ adalah persamaan linier dalam dua variabel. Pada persamaan linear ini berlaku hukum: (1) Ruas kiri dan ruas kanan dapat ditambahkan atau dikurangi bilangan yang sama, dan (2) Ruas kiri dan ruas kanan dapat dikalikan atau dibagi dengan bilangan yang sama (Ayres dan Schmidt, 2004:17). Aljabar ini selanjutnya dinamakan aljabar klasik. Dari sini muncul keinginan untuk mengembangkan persamaan aljabar fuzzy.

\section{KAJIAN TEORI}

\section{Persamaan Linier}

Persamaan linier adalah sebuah persamaan aljabar yang setiap sukunya merupakan konstanta atau perkalian konstanta dengan variabel tunggal. Secara umum persamaan linier dengan $n$ variabel $x_{1}, x_{2}, \ldots, x_{n}$ didefinisikan dengan

$$
a_{1} x_{1}+a_{2} x_{2}+\cdots+a_{n} x_{n}=b
$$

Dengan $a_{1}, a_{2}, \ldots, a_{n}$ dan $b$ adalah konstanta-konstanta riil. Sebuah persamaan linier tidak melibatkan sesuatu hasil kali atau akar variabel. Semua veriabel hanya terdapat sampai dengan derajat pertama dan tidak muncul sebagai argumen untuk fungsi trigonometri, fungsi logaritma, atau fungsi eksponensial (Anton, 2000:17-20). 


\section{Logika Fuzzy (Fuzzy Logic)}

Logika fuzzy merupakan peningkatan dari logika Boolean yang diperkenalkan oleh Dr. Lotfi Zadeh dari Universitas California, Berkeley pada tahun 1965. Dalam logika Boolean menyatakan bahwa segala sesuatu hanya dapat diekspresikan dalam dua nilai, yaitu 0 dan 1 , hitam dan putih, atau ya dan tidak. Dalam logika fuzzy memungkinkan nilai keanggotaan antara 0 dan 1, sehingga dalam logika fuzzy mengenal istilah "hitam, keabuan dan putih", atau "sedikit, lumayan dan sangat".

\section{Himpunan Fuzzy (Fuzzy Set)}

Pada himpunan klasik, keberadaan suatu elemen $x$ dalam suatu himpunan $A$, hanya memiliki dua kemungkinan keanggotaan, yaitu $x$ menjadi anggota $A$ atau $x$ tidak menjadi anggota $A$. Suatu nilai yang menunjukkan seberapa besar tingkat keanggotaan suatu elemen $x$ dalam suatu himpunan $A$ biasa disebut dengan nilai keanggotaan, yang biasa ditulis dengan $\mu_{A}(x)$. Pada himpunan klasik, nilai keanggotaan hanya memasangkan nilai 0 atau 1 untuk unsur-unsur pada semesta pembicaraan, yang menyatakan anggota atau bukan anggota.

Nilai keanggotaan untuk himpunan $A$ adalah fungsi $\mu_{A}: X \rightarrow\{0,1\}$ dengan

$$
\mu_{A}(x)=\left\{\begin{array}{l}
1, \quad \text { jika } x \in A \\
0, \quad \text { jika } x \notin \text { atau } x \in A^{\prime}
\end{array}\right.
$$

(Klir dan Yuan, 1995:6).

Fungsi ini, pada himpunan fuzzy diperluas sehingga nilai yang dipasangkan pada unsurunsur dalam semesta pembicaraan tidak hanya 0 dan 1 saja, tetapi keseluruhan nilai dalam interval $[0,1]$ yang menyatakan derajat keanggotaan suatu unsur pada himpunan yang dibicarakan. Fungsi ini disebut fungsi keanggotaan, dan himpunan yang didefinisikan dengan fungsi keanggotaan ini disebut himpunan fuzzy. Fungsi keanggotaan himpunan fuzzy $A$ pada himpunan semesta $X$, dinotasikan dengan $\mu_{A}$, yaitu:

$$
\mu_{A}: X \rightarrow[0,1]
$$

\section{Operasi Dasar Himpunan Fuzzy}

\section{Operasi “Dan" (Intersection)}

A "dan" B merupakan himpunan fuzzy dari $X$, ditunjukkan sebagai derajat keanggotaan dari $A \cap B$ adalah hasil yang diperoleh dengan mengambil nilai keanggotaan terkecil antarelemen pada himpunan-himpunan yang bersangkutan

$$
\mu_{A \cap B}=\min \left[\mu_{A}(x), \mu_{B}(x)\right], \quad x \in X
$$

Operasi "Atau" (Union)

A "atau" B merupakan himpunan fuzzy dari $X$, ditunjukkan sebagai derajat keanggotaan dari $A \cup B$ adalah hasil yang diperoleh dengan mengambil nilai keanggotaan terbesar antarelemen pada himpunan-himpunan yang bersangkutan

$$
\mu_{A \cup B}=\max \left[\mu_{A}(x), \mu_{B}(x)\right], \quad x \in X
$$

Operasi "Tidak" (Complement)

Operasi "tidak" A merupakan himpunan fuzzy dari $X$, ditunjukkan sebagai derajat keanggotaan dari $A^{\prime}$ ( $A$ komplemen) adalah hasil yang diperoleh dengan mengurangkan nilai keanggotaan elemen pada himpunan yang bersangkutan dari 1

$$
\mu_{A^{\prime}}(x)=1-\mu_{A}(x)
$$

(Kusumadewi dan Purnomo, 2004:24-25).

\section{Fungsi Keanggotaan}

Fungsi keanggotaan (membership function) adalah suatu kurva yang menunjukkan pemetaan titik-titik input data ke dalam nilai keanggotaannya yang memiliki interval antara 0 sampai 1 . Salah satu cara yang dapat digunakan untuk mendapatkan nilai keanggotaan adalah melalui pendekatan fungsi. Nilai keanggotaan didapatkan dari beberapa fungsi keanggotaan, dalam buku yang ditulis oleh Sri Kusumadewi dan Hari Purnomo (2004:8) dijelaskan bahwa ada beberapa fungsi yang dapat digunakan untuk memperoleh nilai keanggotaan, yaitu:

a. Representasi Linier (Linier Naik dan Turun)

b. Representasi Kurva Segitiga

c. Representasi Kurva Trapesium

d. Representasi Kurva-S (Pertumbuhan dan Penyusutan)

e. Representasi Kurva Bentuk Lonceng (Bell Curve)
i. Kelas Kurva Phi $(\pi)$
ii. Kelas Kurva Beta $(\beta)$
iii. Kurva Gauss $(\gamma)$

\section{$\alpha-C U T$}

\section{Definisi 1:}

$\alpha$-cut adalah himpunan tegas dari himpunan fuzzy $A$ yang mempunyai derajat keanggotaan lebih dari atau sama dengan derajat keanggotaan yang ditentukan yang dapat didefinisikan dengan $A_{\alpha}=\left\{x \in A, \mu_{A}(x) \geq \alpha\right\}$. Selain itu juga terdapat strong $\alpha$-cut, yakni himpunan dari himpunan fuzzy $A$ yang mempunyai derajat keanggotaan lebih dari derajat keanggotaan yang ditentukan atau dengan kata lain $A_{\alpha}^{\prime}=\left\{x \in A, \mu_{A}(x)>\alpha\right\}$ (Dubbois dan Prade, 1980:19).

\section{Definisi 2:}

Misalkan $A$ adalah himpunan fuzzy pada $X$. Core dari $A$ adalah himpunan tegas yang memuat semua anggota $A$ yang mempunyai derajat keanggotaan 1 (Sivanandam, Sumathi dan Deepa, 2007:73).

Jadi, core dari $A$ adalah $\left\{x \in A \mid \mu_{A}(x)=1\right\}$.

\section{Definisi 3:}


Misalkan $A$ adalah himpunan fuzzy pada $X$. Support dari $A$ adalah himpunan tegas yang memuat semua anggota $A$ yang mempunyai derajat keanggotaan tidak nol (Klir dan Yuan, 1995:21).

Berdasarkan definisi support, secara matematis dapat ditulis sebagai berikut:

$$
S(A)=\left\{x \in A \mid \mu_{A}(x)>0\right\}
$$

Dalam konteks $X=R$, maka support dari $A$, atau $S(A)$, dikatakan terbatas di atas (bounded above) jika terdapat $r \in R$ sehingga $x \leq r$, untuk setiap $x \in S(A)$. Support dari $A$, atau $S(A)$, dikatakan terbatas di bawah (bounded below) jika terdapat $r \in R$ sehingga $r \leq x$, untuk setiap $x \in S(A)$. Selanjutnya, $S(A)$ dikatakan terbatas (bounded) jika terbatas di atas dan terbatas di bawah (Zhang dan Liu, 2006:6).

Selanjutnya, misalkan $A$ himpunan fuzzy dengan fungsi keanggotaan $\mu_{A}(x)$. Dibentuk himpunan fuzzy baru $A_{\alpha}$ yang didefinisikan dengan

$$
A_{\alpha}=\left\{x \in A \mid \mu_{A_{\alpha}}(x)=\alpha \wedge \chi_{A_{\alpha}}(x)\right\}
$$

maka akan diperoleh bahwa

$$
A=\bigcup_{\alpha \in[0,1]} A_{\alpha}
$$

Hal ini mengakibatkan bahwa himpunan fuzzy $A$ telah didekomposisi ke dalam gabungan dari $A_{\alpha}$, untuk semua $\alpha \in[0,1]$. Pada himpunan fuzzy $A_{\alpha}$ yang didefinisikan di atas diperoleh

$$
\mu_{A_{\alpha}}(x)=\alpha \wedge \chi_{A_{\alpha}}(x)= \begin{cases}\alpha, & x \in A_{\alpha} \\ 0, & x \notin A_{\alpha}\end{cases}
$$

Terdapat korespondensi $1-1$ antara $\mu_{A}(x)$ dengan $A_{\alpha}$, untuk $\alpha \in[0,1]$. Dengan demikian, himpunan fuzzy dapat dinyatakan hanya dalam bentuk $\alpha$ - cut tanpa menyatakan fungsi keanggotaan (Susilo, 2006:74).

\section{Klasifikasi Berdasarkan Fungsi Keanggotaan}

Berdasarkan grafik fungsi keanggotaan, himpunan fuzzy dapat diklasifikasikan ke dalam beberapa klasifikasi yaitu normal, subnormal, konvek dan takkonvek. Sebelumnya akan diberikan definisi titik crossover dan tinggi suatu himpunan fuzzy.

\section{Definisi 4:}

Misalkan $A$ adalah himpunan fuzzy pada $X$. Titik crossover pada $A$ adalah titik yang mempunyai derajat keanggotaan 0.5 (Sivanandam, Sumathi dan Deepa, 2007:74).

Dengan demikian, $x \in A$ disebut titik crossover jika $\mu_{A}(x)=0.5$.

\section{Definisi 5:}

Misalkan $A$ adalah himpunan fuzzy pada $X$. Tinggi dari $A$, dinotasikan dengan $h(A)$, adalah nilai maksimum dari fungsi keanggotaan himpunan $A$ (Sivanandam, Sumathi dan Deepa, 2007:74).
Dengan redaksi yang berbeda George J. Klir dan Bo Yuan (1995:21) mendefinisikan $h(A)$ sebagai derajat keanggotaan terbesar yang dicapai oleh sebarang unsur di $A$. Secara simbolik, dapat dinyatakan bahwa

$$
h(A)=\max \left\{\mu_{A}(x)\right\}
$$

atau

$$
h(A)=\sup \left\{\mu_{A}(x)\right\}
$$

\section{Definisi 6:}

Misalkan $A$ adalah himpunan fuzzy pada $X$. $A$ sebagai himpunan fuzzy normal jika $h(A)=1$ dan subnormal jika $h(A)<1$ (Klir dan Yuan, 1995:21).

\section{Definisi 7:}

Misalkan $A$ adalah himpunan fuzzy pada $X$. Himpunan fuzzy $A$ disebut konvek jika fungsi keanggotaannya monoton naik, atau menoton turun, atau monoton naik dan monoton turun pada saat nilai unsur pada himpunan semesta semakin naik.

Himpunan fuzzy $A$ disebut tak konvek jika fungsi keanggotaannya tidak monoton naik, atau tidak menoton turun, atau monoton naik dan monoton turun pada saat nilai unsur pada himpunan semesta semakin naik (Sivanandam, Sumathi dan Deepa, 2007:75).

Sebagai ilustrasi, perhatikan gambar berikut:

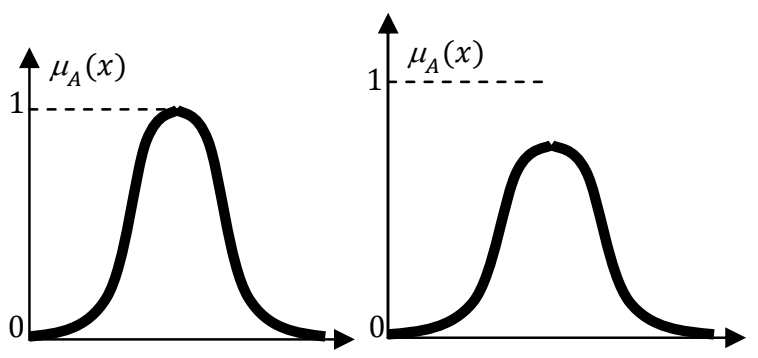

Gambar 1. Himpunan Fuzzy Normal dan Subnormal

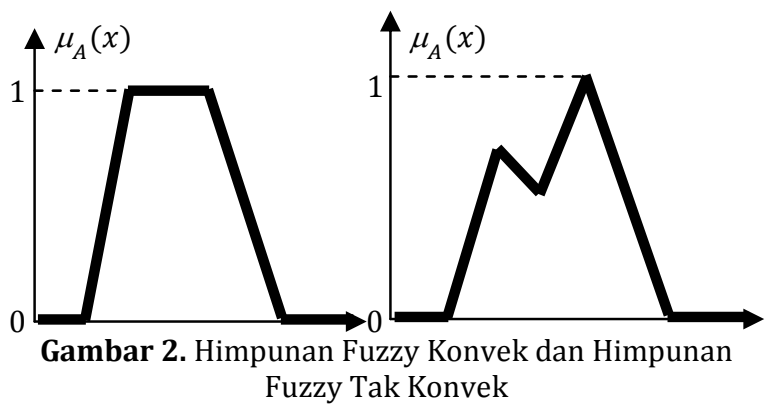

\section{Operasi Aritmetika Fuzzy}

Operasi aritmetika dasar pada bilangan fuzzy merupakan konsep perluasan dari operasi aritmetika dasar pada umumnya, yaitu dengan mengikut sertakan derajat keanggotaannya. Operasi bilangan fuzzy dilakukan dengan memanfaatkan $\alpha$-cut yang berbentuk interval tertutup. 
Misalkan * adalah operasi aritmetika pada interval tertutup (meliputi operasi penjumlahan, pengurangan, perkalian, dan pembagian), maka

$[a, b] *[c, d]=\{f * g \mid a \leq f \leq b, c \leq g \leq d\}$ merupakan aturan umum untuk operasi aritmetika pada interval tertutup, kecuali bahwa $[a, b] /[c, d]$ tidak didefinisikan jika $0 \in[c, d]$. Hasil operasi aritmetika pada interval tertutup juga merupakan interval tertutup.

Operasi aritmetika pada interval tertutup $[a, b]$ dan $[c, d]$, dengan $a \leq b$ dan $c \leq d$ didefinisikan sebagai berikut.

$$
\begin{aligned}
& \text { a. Penjumlahan } \\
& {[a, b]+[c, d]} \\
& =\quad[\min \{a+c, a+d, b+c, b+d\}, \\
& \quad \max \{a+c, a+d, b+c, b+d\}] \\
& =[a+c, b+d] \\
& \text { b. Pengurangan } \\
& {[a, b]-[c, d]} \\
& =\quad[\min \{a-c, a-d, b-c, b-d\}, \\
& \quad \max \{a-c, a-d, b-c, b-d\}] \\
& =[a-d, b-c] \\
& \text { c. } \quad \text { Perkalian } \\
& {[a, b] \cdot[c, d]} \\
& =\quad[\min \{a c, a d, b c, b d\}, \max \{a c, a d, b c, b d\}] \\
& \text { d. Pembagian } \\
& {[a, b] /[c, d]=[a, b] \cdot\left[\frac{1}{c}, \frac{1}{d}\right]} \\
& \quad=\left[\min \left\{\frac{a}{c}, \frac{a}{d}, \frac{b}{c}, \frac{b}{d}\right\}, \max \left\{\frac{a}{c}, \frac{a}{d}, \frac{b}{c}, \frac{b}{d}\right\}\right]
\end{aligned}
$$

dengan syarat $0 \notin[c, d]$

(Klir dan Yuan, 1995:103).

\section{Definisi 8:}

Misalkan $A$ dan $B$ adalah bilangan fuzzy pada semesta $R$ dengan fungsi keanggotaan masingmasing $\mu_{A}(x)$ dan $\mu_{B}(x)$. Misalkan $*$ adalah empat operasi aritmetika dasar pada $R$. Didefinisikan operasi $A * B$ dengan menggunakan definisi $\alpha$-cut, $(A * B)_{\alpha}$ sebagai persamaan berikut:

$$
(A * B)_{\alpha}=A_{\alpha} * B_{\alpha}
$$

Untuk setiap $\alpha \in$ [0,1] (Klir dan Yuan, 1995:105).

Sehingga $A * B$ dapat ditulis sebagai

dengan

$$
A * B=\bigcup_{\alpha \in(0,1]}(A * B)_{\alpha}
$$

$$
(A * B)_{\alpha}=\alpha \wedge \chi_{(A * B)_{\alpha}}(x)= \begin{cases}\alpha, & x \in(A * B)_{\alpha} \\ 0, & x \notin(A * B)_{\alpha}\end{cases}
$$
dan

$$
\chi_{(A * B)_{\alpha}}(x)= \begin{cases}1, & x \in(A * B)_{\alpha} \\ 0, & x \notin(A * B)_{\alpha}\end{cases}
$$

Selama $(A * B)_{\alpha}$ adalah interval tertutup untuk setiap $\alpha \in[0,1], A$ dan $B$ adalah bilangan fuzzy, maka $A * B$ juga bilangan fuzzy.

Sehingga secara khusus, diperoleh Penjumlahan $:(A+B)_{\alpha}=A_{\alpha}+B_{\alpha}$ Pengurangan $:(A-B)_{\alpha}=A_{\alpha}-B_{\alpha}$
Perkalian $\quad:(A \cdot B)_{\alpha}=A_{\alpha} \cdot B_{\alpha}$

Pembagian $\quad:(A / B)_{\alpha}=A_{\alpha} / B_{\alpha}$, dengan syarat $0 \notin B_{\alpha}$.

\section{Bilangan Fuzzy}

\section{Definisi 9:}

Misalkan $A$ adalah himpunan fuzzy pada $R$. $A$ disebut bilangan fuzzy jika memenuhi syaratsyarat berikut:

1. A merupakan himpunan fuzzy normal,

2. $A_{\alpha}$ merupakan interval tertutup untuk semua $\alpha \in(0,1]$, dan

3. $S(A)$, atau $A_{0+}$, merupakan himpunan terbatas (Klir dan Yuan, 1995:97).

Syarat bahwa $A_{\alpha}$ merupakan interval tertutup untuk semua $\alpha \in(0,1]$ sama dengan syarat bahwa $A$ merupakan himpunan konvek. Bilangan fuzzy sebagai himpunan fuzzy normal dan konvek, dan setiap $\alpha$-cut merupakan interval tertutup. Jadi, bilangan fuzzy adalah himpunan konvek, normal, dan merupakan interval tertutup (Chen dan Pham, 2001:42).

\section{PEMBAHASAN}

Secara umum bilangan fuzzy didefinisikan sebagai himpunan fuzzy dalam semesta himpunan semua bilangan riil $R$ yang memenuhi empat sifat diantaranya yaitu: normal, mempunyai support yang terbatas, semua $\alpha$-cut adalah selang tertutup dalam $R$, dan konveks.

Suatu bilangan fuzzy bersifat normal jika mempunyai nilai fungsi keanggotaannya sama dengan 1 dan sifat lainnya digunakan untuk dapat mendefinisikan operasi-operasi aritmetika (penjumlahan, pengurangan, perkalian, dan pembagian) pada bilangan fuzzy. Operasi bilangan fuzzy dilakukan dengan memanfaatkan $\alpha$-cut yang berbentuk interval tertutup. Misalkan $\tilde{A}$ dan $\tilde{B}$ adalah bilangan fuzzy pada semesta $R$ dengan fungsi keanggotaan masing-masing $\mu_{A}(x)$ dan $\mu_{B}(x)$, dan $*$ adalah empat operasi aritmetika dasar pada $R$. Maka $(A * B)_{\alpha}=A_{\alpha} * B_{\alpha}$ untuk setiap $\alpha \in[0,1]$.

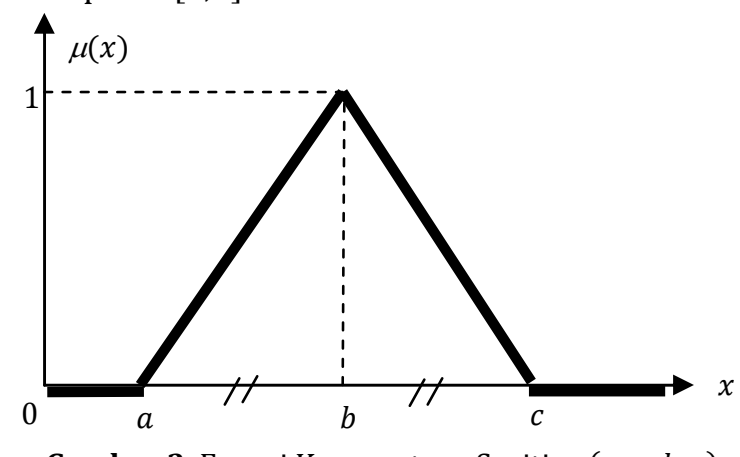

Gambar 3. Fungsi Keanggotaan Segitiga $(x ; a, b, c)$

Fungsi keanggotaan segitiga diperoleh dari persamaan garis dari titik ke titik, yaitu dengan 
titik $a(a, 0), b(b, 1)$, dan $c(c, 0)$. Yang selanjutnya fungsi keanggotaan dari bilangan fuzzy segitiga $\tilde{A}$ dapat dinyatakan dengan

$$
\mu_{A}(x)= \begin{cases}\frac{x-a}{b-a}, & a \leq x \leq b \\ \frac{c-x}{c-b}, & b<x \leq c \\ 0, & x<a \text { atau } x>c\end{cases}
$$

Kemudian akan ditentukan nilai $\alpha$-cut dari bilangan fuzzy dengan fungsi keanggotaan segitiga. Dari bilangan $\tilde{A}$, dengan menyatakan

diperoleh

$$
\alpha=\frac{x-a}{b-a}
$$

dan untuk

$$
x=(b-a) \alpha+a
$$

diperoleh

$$
\alpha=\frac{c-x}{c-b}
$$

$$
x=c-(c-b) \alpha
$$

Jadi bilangan fuzzy $\tilde{A}$ pada semesta $R$ dapat ditulis ulang menjadi:

$$
A_{\alpha}=[(b-a) \alpha+a, c-(c-b) \alpha]
$$

Selanjutnya untuk mendapatkan generalisasi dari masing-masing operasi aritmetika, diberikan contoh fungsi keanggotaan bilangan fuzzy dengan interval 1 satuan, interval 2 satuan, interval 3 satuan, dan interval $n$ satuan. Contoh pertama operasi aritmetika penjumlahan $\tilde{a}+\tilde{b}=\tilde{x}$, dimana $\tilde{a}$ dan $\tilde{b}$ adalah bilangan fuzzy dalam $R$.

1. Operasi aritmetika penjumlahan dengan interval 1 satuan

Bilangan fuzzy $\tilde{a}$ dan $\tilde{b}$ mempunyai fungsi keanggotaan

dan

$$
\tilde{a}=\operatorname{segitiga}(x ; a-1, a, a+1)
$$

$$
\tilde{b}=\operatorname{segitiga}(x ; b-1, b, b+1)
$$

Dari bilangan fuzzy $\tilde{a}$ dan $\tilde{b}$ dapat dinyatakan dalam $\alpha$-cut untuk $\alpha \in[0,1]$, yaitu

dan

$$
a_{\alpha}=[\alpha+a-1, a+1-\alpha]
$$

$$
b_{\alpha}=[\alpha+b-1, b+1-\alpha]
$$

Dengan menggunakan definisi operasi aritmetika pada interval, diperoleh

$$
x_{\alpha}=a_{\alpha}+b_{\alpha}
$$

$$
=[2 \alpha+a+b-2, a+b+2-2 \alpha]
$$

untuk setiap $\alpha \in[0,1]$.

Sehingga selesaian dari persamaan fuzzy $\tilde{a}+\tilde{b}=\tilde{x}$ adalah:

$$
\begin{gathered}
\tilde{x}=\bigcup_{\alpha \in[0,1]} \tilde{x}_{\alpha} \\
=\operatorname{segitiga}(x ; a+b-2, a+b, a+b+2) \\
=\widetilde{a+b}
\end{gathered}
$$

2. Operasi aritmetika penjumlahan dengan interval 2 satuan

Bilangan fuzzy $\tilde{a}$ dan $\tilde{b}$ mempunyai fungsi keanggotaan

$$
\tilde{a}=\operatorname{segitiga}(x ; a-2, a, a+2)
$$

dan

$$
\tilde{b}=\operatorname{segitig} a(x ; b-2, b, b+2)
$$

Dari bilangan fuzzy $\tilde{a}$ dan $\tilde{b}$ dapat dinyatakan dalam $\alpha$-cut untuk $\alpha \in[0,1]$, yaitu

dan

$$
\begin{aligned}
& a_{\alpha}=[2 \alpha+a-2, a+2-2 \alpha] \\
& b_{\alpha}=[2 \alpha+b-2, b+2-2 \alpha]
\end{aligned}
$$

Dengan menggunakan definisi operasi aritmetika pada interval, diperoleh

$$
x_{\alpha}=a_{\alpha}+b_{\alpha}
$$$$
=[4 \alpha+a+b-4, a+b+4-4 \alpha]
$$

untuk setiap $\alpha \in[0,1]$.

Sehingga selesaian dari persamaan fuzzy $\tilde{a}+\tilde{b}=\tilde{x}$ adalah:

$$
\begin{gathered}
\tilde{x}=\bigcup_{\alpha \in[0,1]} \tilde{x}_{\alpha} \\
=\operatorname{segitiga}(x ; a+b-4, a+b, a+b+4) \\
=\widetilde{a+b}
\end{gathered}
$$

3. Operasi aritmetika penjumlahan dengan interval 3 satuan

Bilangan fuzzy $\tilde{a}$ dan $\tilde{b}$ mempunyai fungsi keanggotaan

$$
\begin{aligned}
\operatorname{dan} \quad & \tilde{a}=\operatorname{segitiga}(x ; a-3, a, a+3) \\
& \tilde{b}=\operatorname{segitiga}(x ; b-3, b, b+3)
\end{aligned}
$$

Dari bilangan fuzzy $\tilde{a}$ dan $\tilde{b}$ dapat dinyatakan dalam $\alpha$-cut untuk $\alpha \in[0,1]$, yaitu

$$
a_{\alpha}=[3 \alpha+a-3, a+3-3 \alpha]
$$

dan

$$
b_{\alpha}[3 \alpha+b-3, b+3-3 \alpha]
$$

Dengan menggunakan definisi operasi aritmetika pada interval, diperoleh

$$
\begin{gathered}
x_{\alpha}=a_{\alpha}+b_{\alpha} \\
=[6 \alpha+a+b-6, a+b+6-6 \alpha]
\end{gathered}
$$

untuk setiap $\alpha \in[0,1]$.

Sehingga selesaian dari persamaan fuzzy $\tilde{a}+\tilde{b}=\tilde{x}$ adalah:

$$
\begin{gathered}
\tilde{x}=\bigcup_{\alpha \in[0,1]} \tilde{x}_{\alpha} \\
=\operatorname{segitiga}(x ; a+b-6, a+b, a+b+6) \\
=\widetilde{a+b}
\end{gathered}
$$

4. Operasi aritmetika penjumlahan dengan interval $n$ satuan

Bilangan fuzzy $\tilde{a}$ dan $\tilde{b}$ mempunyai fungsi keanggotaan

dan

$$
\tilde{a}=\operatorname{segitig} a(x ; a-n, a, a+n)
$$

$$
\tilde{b}=\operatorname{segitiga}(x ; b-n, b, b+n)
$$

Dari bilangan fuzzy $\tilde{a}$ dan $\tilde{b}$ dapat dinyatakan dalam $\alpha$-cut untuk $\alpha \in[0,1]$, yaitu

dan

$$
a_{\alpha}=[n \alpha+a-n, a+n-n \alpha]
$$

$$
b_{\alpha}=[n \alpha+b-n, b+n-n \alpha]
$$

Dengan menggunakan definisi operasi aritmetika pada interval, diperoleh

$$
\begin{gathered}
x_{\alpha}=a_{\alpha}+b_{\alpha} \\
=[2 n \alpha+a+b-2 n, a+b+2 n-2 n \alpha]
\end{gathered}
$$


untuk setiap $\alpha \in[0,1]$.

Sehingga selesaian dari persamaan fuzzy $\tilde{a}+\tilde{b}=\tilde{x}$ adalah:

$$
\begin{gathered}
\tilde{x}=\bigcup_{\alpha \in[0,1]} \tilde{x}_{\alpha} \\
=\operatorname{segitiga}(x ; a+b-2 n, a+b, a+b+2 n) \\
=\widetilde{a+b}
\end{gathered}
$$

Dari contoh operasi aritmetika penjumlahan di atas, dapat digeneralisasikan sebagai berikut:

Misalkan bilangan fuzzy $\tilde{A}$ dan $\tilde{B}$ di $R$ berturutturut yaitu

dan

$$
\tilde{A}=\operatorname{segitiga}(x ; a, b, c)
$$

maka

$$
\tilde{B}=\operatorname{segitiga}(x ; d, e, f)
$$

$\tilde{A}+\widetilde{B}=\operatorname{segitiga}(x ; a+d, b+e, c+f)$

Contoh kedua untuk operasi aritmetika pengurangan $\tilde{a}-\tilde{b}=\tilde{x}$, dimana $\tilde{a}$ dan $\tilde{b}$ adalah bilangan fuzzy dalam $R$

1. Operasi aritmetika pengurangan dengan interval 1 satuan

Bilangan fuzzy $\tilde{a}$ dan $\tilde{b}$ mempunyai fungsi keanggotaan

dan

$$
\tilde{a}=\operatorname{segitiga}(x ; a-1, a, a+1)
$$

$$
\tilde{b}=\operatorname{segitiga}(x ; b-1, b, b+1)
$$

Dari bilangan fuzzy $\tilde{a}$ dan $\tilde{b}$ dapat dinyatakan dalam $\alpha$-cut untuk $\alpha \in[0,1]$, yaitu

dan

$$
a_{\alpha}=[\alpha+a-1, a+1-\alpha]
$$

$$
b_{\alpha}[\alpha+b-1, b+1-\alpha]
$$

Dengan menggunakan definisi aritmetika pada interval, diperoleh

$$
\begin{gathered}
x_{\alpha}=a_{\alpha}-b_{\alpha} \\
=[2 \alpha+a-b-2, a-b+2-2 \alpha]
\end{gathered}
$$

untuk setiap $\alpha \in[0,1]$.

Sehingga selesaian dari persamaan fuzzy $\tilde{a}-\tilde{b}=\tilde{x}$ adalah:

$$
\begin{gathered}
\tilde{x}=\bigcup_{\alpha \in[0,1]} \tilde{x}_{\alpha} \\
=\operatorname{segitiga}(x ; a-b-2, a-b, a-b+2)
\end{gathered}
$$

2. Operasi aritmetika pengurangan dengan interval 2 satuan

Bilangan fuzzy $\tilde{a}$ dan $\tilde{b}$ mempunyai fungsi keanggotaan

dan

$$
\tilde{a}=\operatorname{segitiga}(x ; a-2, a, a+2)
$$

$$
\tilde{b}=\operatorname{segitiga}(x ; b-2, b, b+2)
$$

Dari bilangan fuzzy $\tilde{a}$ dan $\tilde{b}$ dapat dinyatakan dalam $\alpha$-cut untuk $\alpha \in[0,1]$, yaitu

dan

$$
a_{\alpha}=[2 \alpha+a-2, a+2-2 \alpha]
$$

$$
b_{\alpha}=[2 \alpha+b-2, b+2-2 \alpha]
$$

Dengan menggunakan definisi operasi aritmetika pada interval, diperoleh

$$
\begin{gathered}
x_{\alpha}=a_{\alpha}-b_{\alpha} \\
=[4 \alpha+a-b-4, a-b+4-4 \alpha]
\end{gathered}
$$

untuk setiap $\alpha \in[0,1]$.

Sehingga selesaian dari persamaan fuzzy $\tilde{a}-\tilde{b}=\tilde{x}$ adalah:

$$
\begin{gathered}
\tilde{x}=\bigcup_{\alpha \in[0,1]} \tilde{x}_{\alpha} \\
=\operatorname{segitiga}(x ; a-b-4, a-b, a-b+4) \\
=\widetilde{a-b}
\end{gathered}
$$

3. Operasi aritmetika pengurangan dengan interval 3 satuan

Bilangan fuzzy $\tilde{a}$ dan $\tilde{b}$ mempunyai fungsi keanggotaan

$$
\begin{aligned}
\operatorname{dan} \quad & \tilde{a}=\operatorname{segitiga}(x ; a-3, a, a+3) \\
& \tilde{b}=\operatorname{segitiga}(x ; b-3, b, b+3)
\end{aligned}
$$

Dari bilangan fuzzy $\tilde{a}$ dan $\tilde{b}$ dapat dinyatakan dalam $\alpha$-cut untuk $\alpha \in[0,1]$, yaitu

dan

$$
a_{\alpha}=[3 \alpha+a-3, a+3-3 \alpha]
$$

$$
b_{\alpha}=[3 \alpha+b-3, b+3-3 \alpha]
$$

Dengan menggunakan definisi operasi aritmetika pada interval, diperoleh

$$
\begin{gathered}
x_{\alpha}=a_{\alpha}-b_{\alpha} \\
=[6 \alpha+a-b-6, a-b+6-6 \alpha]
\end{gathered}
$$

untuk setiap $\alpha \in[0,1]$.

Sehingga selesaian dari persamaan fuzzy $\tilde{a}-\tilde{b}=\tilde{x}$ adalah:

$$
\begin{gathered}
\tilde{x}=\bigcup_{\alpha \in[0,1]} \tilde{x}_{\alpha} \\
=\operatorname{segitiga}(x ; a-b-6, a-b, a-b+6) \\
=\widetilde{a-b}
\end{gathered}
$$

4. Operasi aritmetika pengurangan dengan interval $n$ satuan

Bilangan fuzzy $\tilde{a}$ dan $\tilde{b}$ mempunyai fungsi keanggotaan

$$
\begin{aligned}
\operatorname{dan} \quad & \tilde{a}=\operatorname{segitiga}(x ; a-n, a, a+n) \\
& \tilde{b}=\operatorname{segitiga}(x ; b-n, b, b+n)
\end{aligned}
$$

Dari bilangan fuzzy $\tilde{a}$ dan $\tilde{b}$ dapat dinyatakan dalam $\alpha$-cut untuk $\alpha \in[0,1]$, yaitu

$$
b_{\alpha}=[n \alpha+b-n, b+n-n \alpha]
$$$$
a_{\alpha}=[n \alpha+a-n, a+n-n \alpha]
$$

dan

Dengan menggunakan definisi operasi aritmetika pada interval, diperoleh

$$
\begin{gathered}
x_{\alpha}=a_{\alpha}-b_{\alpha} \\
=[2 n \alpha+a-b-2 n, a-b+2 n-2 n \alpha]
\end{gathered}
$$

untuk setiap $\alpha \in[0,1]$.

Sehingga selesaian dari persamaan fuzzy $\tilde{a}-\tilde{b}=\tilde{x}$ adalah:

$$
\begin{gathered}
\tilde{x}=\bigcup_{\alpha \in[0,1]} \tilde{x}_{\alpha} \\
=\operatorname{segitiga}(x ; a-b-2 n, a-b, a-b+2 n) \\
=\widetilde{a-b}
\end{gathered}
$$


Dari contoh operasi aritmetika pengurangan di atas, dapat digeneralisasikan sebagai berikut:

Misalkan bilangan fuzzy $\tilde{A}$ dan $\tilde{B}$ di $R$ berturutturut yaitu

dan

$$
\tilde{A}=\operatorname{segitig} a(x ; a, b, c)
$$

$$
\tilde{B}=\operatorname{segitiga}(x ; d, e, f)
$$

maka

$$
\tilde{A}-\tilde{B}=\operatorname{segitiga}(x ; a-f, b-e, c-d)
$$

Contoh ketiga untuk operasi aritmetika perkalian $\tilde{a} \cdot \tilde{b}=\tilde{x}$, dimana $\tilde{a}$ dan $\tilde{b}$ adalah bilangan fuzzy dalam $R$

1. Operasi aritmetika perkalian dengan interval 1 satuan

Bilangan fuzzy $\tilde{a}$ dan $\tilde{b}$ mempunyai fungsi keanggotaan

dan

$$
\tilde{a}=\operatorname{segitiga}(x ; a-1, a, a+1)
$$

$$
\tilde{b}=\operatorname{segitiga}(x ; b-1, b, b+1)
$$

Dari bilangan fuzzy $\tilde{a}$ dan $\tilde{b}$ dapat dinyatakan dalam $\alpha$-cut untuk $\alpha \in[0,1]$, yaitu

dan

$$
a_{\alpha}=[\alpha+a-1, a+1-\alpha]
$$

$b_{\alpha}=[\alpha+b-1, b+1-\alpha]$

Dengan menggunakan definisi operasi aritmetika pada interval, diperoleh

$$
\begin{gathered}
x_{\alpha}=a_{\alpha} \cdot b_{\alpha} \\
=\left[\operatorname { m i n } \left(\left(\alpha^{2}+(a+b-2) \alpha+a b-a-b\right.\right.\right. \\
+1),\left(-\alpha^{2}-(a-b-2) \alpha\right. \\
+a b+a-b-1),\left(-\alpha^{2}\right. \\
+(a-b+2) \alpha+a b-a+b \\
\quad-1),\left(\alpha^{2}-(a+b+2) \alpha\right. \\
+a b+a+b+1)), \max \left(\left(\alpha^{2}\right.\right. \\
+(a+b-2) \alpha+a b-a-b \\
+1),\left(-\alpha^{2}-(a-b-2) \alpha\right. \\
+a b+a-b-1),\left(-\alpha^{2}\right. \\
+(a-b+2) \alpha+a b-a+b \\
+1),\left(\alpha^{2}-(a+b+2) \alpha\right. \\
+a b+a+b+1))]
\end{gathered}
$$

untuk setiap $\alpha \in[0,1]$.

2. Operasi aritmetika perkalian dengan interval 2 satuan

Bilangan fuzzy $\tilde{a}$ dan $\tilde{b}$ mempunyai fungsi keanggotaan

dan

$$
\tilde{a}=\operatorname{segitiga}(x ; a-2, a, a+2)
$$

$$
\tilde{b}=\operatorname{segitiga}(x ; b-2, b, b+2)
$$

Dari bilangan fuzzy $\tilde{a}$ dan $\tilde{b}$ dapat dinyatakan dalam $\alpha$-cut untuk $\alpha \in[0,1]$, yaitu

dan

$$
a_{\alpha}=[2 \alpha+a-2, a+2-2 \alpha]
$$

$$
b_{\alpha}=[2 \alpha+b-2, b+2-2 \alpha]
$$

Dengan menggunakan definisi operasi aritmetika pada interval, diperoleh

$$
x_{\alpha}=a_{\alpha} \cdot b_{\alpha}
$$

$$
\begin{aligned}
=\min \left(\left(4 \alpha^{2}\right.\right. & +(2 a+2 b-8) \alpha+a b-2 a \\
& -2 b+4),\left(-4 \alpha^{2}\right. \\
& -(2 a-2 b-8) \alpha+a b+2 a \\
& -2 b-4),\left(-4 \alpha^{2}\right. \\
& +(2 a-2 b+8) \alpha+a b-2 a \\
& +2 b-4),\left(4 \alpha^{2}\right. \\
& -(2 a+2 b+8) \alpha+a b+2 a \\
& +2 b+4)), \max \left(\left(4 \alpha^{2}\right.\right. \\
& +(2 a+2 b-8) \alpha+a b-2 a \\
& -2 b+4),\left(-4 \alpha^{2}\right. \\
& -(2 a-2 b-8) \alpha+a b+2 a \\
& -2 b-4),\left(-4 \alpha^{2}\right. \\
& +(2 a-2 b+8) \alpha+a b-2 a \\
& +2 b-4),\left(4 \alpha^{2}\right. \\
& -(2 a+2 b+8) \alpha+a b+2 a \\
& +2 b+4))]
\end{aligned}
$$

untuk setiap $\alpha \in[0,1]$.

3. Operasi aritmetika perkalian dengan interval 3 satuan

Bilangan fuzzy $\tilde{a}$ dan $\tilde{b}$ mempunyai fungsi keanggotaan

dan

$$
\tilde{a}=\operatorname{segitiga}(x ; a-3, a, a+3)
$$

$$
\tilde{b}=\operatorname{segitig} a(x ; b-3, b, b+3)
$$

Dari bilangan fuzzy $\tilde{a}$ dan $\tilde{b}$ dapat dinyatakan dalam $\alpha$-cut untuk $\alpha \in[0,1]$, yaitu

dan

$$
a_{\alpha}=[3 \alpha+a-3, a+3-3 \alpha]
$$

$$
b_{\alpha}=[3 \alpha+b-3, b+3-3 \alpha]
$$

Dengan menggunakan definisi operasi aritmetika pada interval, diperoleh

$$
x_{\alpha}=a_{\alpha} \cdot b_{\alpha}
$$

$$
=\left[\operatorname { m i n } \left(\left(9 \alpha^{2}+(3 a+3 b-18) \alpha+a b-3 a\right.\right.\right.
$$$$
-3 b+9),\left(-9 \alpha^{2}\right.
$$$$
-(3 a-3 b-18) \alpha+a b
$$$$
+3 a-3 b-9),\left(-9 \alpha^{2}\right.
$$$$
+(3 a-3 b+18) \alpha+a b
$$$$
-3 a+3 b-9),\left(9 \alpha^{2}\right.
$$$$
-(3 a+3 b+18) \alpha+a b
$$$$
+3 a+3 b+9)), \max \left(\left(9 \alpha^{2}\right.\right.
$$

$+(3 a+3 b-18) \alpha+a b$

$-3 a-3 b+9),\left(-9 \alpha^{2}\right.$

$-(3 a-3 b-18) \alpha+a b$

$+3 a-3 b-9),\left(-9 \alpha^{2}\right.$

$+(3 a-3 b+18) \alpha+a b$

$-3 a+3 b-9),\left(9 \alpha^{2}\right.$

$-(3 a+3 b+18) \alpha+a b$

$+3 a+3 b+9))]$

untuk setiap $\alpha \in[0,1]$.

4. Operasi aritmetika perkalian dengan interval $n$ satuan

Bilangan fuzzy $\tilde{a}$ dan $\tilde{b}$ mempunyai fungsi keanggotaan

$$
\begin{aligned}
\operatorname{dan} \quad & =\operatorname{segitiga}(x ; a-n, a, a+n) \\
\tilde{b} & =\operatorname{segitiga}(x ; b-n, b, b+n)
\end{aligned}
$$


Dari bilangan fuzzy $\tilde{a}$ dan $\tilde{b}$ dapat dinyatakan dalam $\alpha$-cut untuk $\alpha \in[0,1]$, yaitu

dan

$$
a_{\alpha}=[n \alpha+a-n, a+n-n \alpha]
$$

$$
b_{\alpha}=[n \alpha+b-n, b+n-n \alpha]
$$

Dengan menggunakan definisi operasi aritmetika pada interval, diperoleh

$$
\begin{aligned}
& x_{\alpha}=a_{\alpha} \cdot b_{\alpha} \\
=\left[\operatorname { m i n } \left(\left(n^{2} \alpha^{2}+\right.\right.\right. & \left(n a+n b-2 n^{2}\right) \alpha+a b-n a \\
& \left.-n b+n^{2}\right),\left(-n^{2} \alpha^{2}\right. \\
& -\left(n a-n b-2 n^{2}\right) \alpha+a b \\
& \left.+n a-n b-n^{2}\right),\left(-n^{2} \alpha^{2}\right. \\
& +\left(n a-n b+2 n^{2}\right) \alpha+a b \\
& \left.-n a+n b-n^{2}\right),\left(n^{2} \alpha^{2}\right. \\
& -\left(n a+n b+2 n^{2}\right) \alpha+a b \\
& +n a+n b \\
& \left.\left.+n^{2}\right)\right), \max \left(\left(n^{2} \alpha^{2}\right.\right. \\
& +\left(n a+n b-2 n^{2}\right) \alpha+a b \\
& \left.-n a-n b+n^{2}\right),\left(-n^{2} \alpha^{2}\right. \\
& -\left(n a-n b-2 n^{2}\right) \alpha+a b \\
& \left.+n a-n b-n^{2}\right),\left(-n^{2} \alpha^{2}\right. \\
& +\left(n a-n b+2 n^{2}\right) \alpha+a b \\
& \left.-n a+n b-n^{2}\right),\left(n^{2} \alpha^{2}\right. \\
& -\left(n a+n b+2 n^{2}\right) \alpha+a b \\
& \left.\left.\left.+n a+n b+n^{2}\right)\right)\right]
\end{aligned}
$$

untuk setiap $\alpha \in[0,1]$.

Contoh keempat untuk operasi aritmetika pembagian $\frac{\tilde{a}}{\tilde{b}}=\tilde{x}$, dimana $\tilde{a}$ dan $\tilde{b}$ adalah bilangan fuzzy dalam $R$

1. Operasi aritmetika pembagian dengan interval 1 satuan

Bilangan fuzzy $\tilde{a}$ dan $\tilde{b}$ mempunyai fungsi keanggotaan

dan

$$
\tilde{a}=\operatorname{segitiga}(x ; a-1, a, a+1)
$$

$$
\tilde{b}=\operatorname{segitig} a(x ; b-1, b, b+1)
$$

Dari bilangan fuzzy $\tilde{a}$ dan $\tilde{b}$ dapat dinyatakan dalam $\alpha$-cut untuk $\alpha \in[0,1]$, yaitu

dan

$$
a_{\alpha}=[\alpha+a-1, a+1-\alpha]
$$

$$
b_{\alpha}=[\alpha+b-1, b+1-\alpha]
$$

Dengan menggunakan definisi operasi aritmetika pada interval, diperoleh

$$
\begin{aligned}
x_{\alpha}= & \frac{a_{\alpha}}{b_{\alpha}} \\
= & {\left[\operatorname { m i n } \left(\frac{\alpha+a-1}{\alpha+b-1}, \frac{\alpha+a-1}{b+1-\alpha}, \frac{a+1-\alpha}{\alpha+b-1},\right.\right.} \\
& \left.\frac{a+1-\alpha}{b+1-\alpha}\right), \max \left(\frac{\alpha+a-1}{\alpha+b-1}, \frac{\alpha+a-1}{b+1-\alpha},\right. \\
& \left.\left.\frac{a+1-\alpha}{\alpha+b-1}, \frac{a+1-\alpha}{b+1-\alpha}\right)\right]
\end{aligned}
$$$$
\text { untuk setiap } \alpha \in[0,1] \text {. }
$$

2. Operasi aritmetika pembagian dengan interval 2 satuan

Bilangan fuzzy $\tilde{a}$ dan $\tilde{b}$ mempunyai fungsi keanggotaan

$$
\tilde{a}=\operatorname{segitiga}(x ; a-2, a, a+2)
$$

dan

$$
\tilde{b}=\operatorname{segitig} a(x ; b-2, b, b+2)
$$

Dari bilangan fuzzy $\tilde{a}$ dan $\tilde{b}$ dapat dinyatakan dalam $\alpha$-cut untuk $\alpha \in[0,1]$, yaitu

$$
\begin{aligned}
\operatorname{dan} \quad a_{\alpha} & =[2 \alpha+a-2, a+2-2 \alpha] \\
b_{\alpha} & =[2 \alpha+b-2, b+2-2 \alpha]
\end{aligned}
$$

Dengan menggunakan definisi 9 operasi aritmetika pada interval, diperoleh $x_{\alpha}=\frac{a_{\alpha}}{b_{\alpha}}$

$$
\begin{aligned}
= & {\left[\operatorname { m i n } \left(\frac{2 \alpha+a-2}{2 \alpha+b-2}, \frac{2 \alpha+a-2}{b+2-2 \alpha}, \frac{a+2-2 \alpha}{2 \alpha+b-2},\right.\right.} \\
& \left.\frac{a+2-2 \alpha}{b+2-2 \alpha}\right), \max \left(\frac{2 \alpha+a-2}{2 \alpha+b-2}, \frac{2 \alpha+a-2}{b+2-2 \alpha},\right. \\
& \left.\left.\frac{a+2-2 \alpha}{2 \alpha+b-2}, \frac{a+2-2 \alpha}{b+2-2 \alpha}\right)\right]
\end{aligned}
$$

untuk setiap $\alpha \in[0,1]$.

3. Operasi aritmetika pembagian dengan interval 3 satuan

Bilangan fuzzy $\tilde{a}$ dan $\tilde{b}$ mempunyai fungsi keanggotaan

$$
\begin{aligned}
\operatorname{dan} \quad & \tilde{a}=\operatorname{segitiga}(x ; a-3, a, a+3) \\
\tilde{b} & =\operatorname{segitiga}(x ; b-3, b, b+3)
\end{aligned}
$$

Dari bilangan fuzzy $\tilde{a}$ dan $\tilde{b}$ dapat dinyatakan dalam $\alpha$-cut untuk $\alpha \in[0,1]$, yaitu

$$
\begin{aligned}
\text { dan } \quad a_{\alpha} & =[3 \alpha+a-3, a+3-3 \alpha] \\
b_{\alpha} & =[3 \alpha+b-3, b+3-3 \alpha]
\end{aligned}
$$

Dengan menggunakan definisi operasi aritmetika pada interval, diperoleh

$$
\begin{aligned}
x_{\alpha}= & \frac{a_{\alpha}}{b_{\alpha}} \\
= & {\left[\operatorname { m i n } \left(\frac{3 \alpha+a-3}{3 \alpha+b-3}, \frac{3 \alpha+a-3}{b+3-3 \alpha}, \frac{a+3-3 \alpha}{3 \alpha+b-3},\right.\right.} \\
& \left.\frac{a+3-3 \alpha}{b+3-3 \alpha}\right), \max \left(\frac{3 \alpha+a-3}{3 \alpha+b-3}, \frac{3 \alpha+a-3}{b+3-3 \alpha},\right. \\
& \left.\left.\frac{a+3-3 \alpha}{3 \alpha+b-3}, \frac{a+3-3 \alpha}{b+3-3 \alpha}\right)\right]
\end{aligned}
$$$$
\text { untuk setiap } \alpha \in[0,1] \text {. }
$$

4. Operasi aritmetika pembagian dengan interval $n$ satuan

Bilangan fuzzy $\tilde{a}$ dan $\tilde{b}$ mempunyai fungsi keanggotaan

$$
\begin{aligned}
\operatorname{dan} \quad \tilde{a} & =\operatorname{segitiga}(x ; a-n, a, a+n) \\
\tilde{b} & =\operatorname{segitiga}(x ; b-n, b, b+n)
\end{aligned}
$$

Dari bilangan fuzzy $\tilde{a}$ dan $\tilde{b}$ dapat dinyatakan dalam $\alpha$-cut untuk $\alpha \in[0,1]$, yaitu

$$
\text { dan } \quad \begin{aligned}
a_{\alpha} & =[n \alpha+a-n, a+n-n \alpha] \\
b_{\alpha} & =[n \alpha+b-n, b+n-n \alpha]
\end{aligned}
$$

Dengan menggunakan definisi operasi aritmetika pada interval, diperoleh

$$
\begin{aligned}
& x_{\alpha}=\frac{a_{\alpha}}{b_{\alpha}} \\
& =\left[\operatorname { m i n } \left(\frac{n \alpha+a-n}{n \alpha+b-n}, \frac{n \alpha+a-n}{b+n-n \alpha}, \frac{a+n-n \alpha}{n \alpha+b-n},\right.\right.
\end{aligned}
$$




$$
\begin{aligned}
& \left.\frac{a+n-n \alpha}{b+n-n \alpha}\right), \max \left(\frac{n \alpha+a-n}{n \alpha+b-n}, \frac{n \alpha+a-n}{b+n-n \alpha},\right. \\
& \left.\left.\quad \frac{a+n-n \alpha}{n \alpha+b-n}, \frac{a+n-n \alpha}{b+n-n \alpha}\right)\right] \\
& \text { untuk setiap } \alpha \in[0,1] .
\end{aligned}
$$

\section{Contoh 1:}

Cari penyelesaian persamaan fuzzy $\tilde{7}+\tilde{5}=\tilde{x}$.

Bilangan fuzzy $\tilde{7}$ dan $\tilde{5}$ mempunyai fungsi keanggotaan

$$
\tilde{7}=\operatorname{segitiga}(x ; 4,7,10)
$$

dan

$$
\tilde{5}=\operatorname{segitiga}(x ; 3,5,7)
$$

Dari bilangan $\tilde{7}$ dapat dinyatakan dalam $\alpha$-cut untuk $\alpha \in[0,1]$, yaitu

$$
7_{\alpha}=[3 \alpha+4,10-3 \alpha]
$$

Dan dari bilangan $\tilde{5}$ dapat dinyatakan dalam $\alpha$ cut untuk $\alpha \in[0,1]$, yaitu

$$
5_{\alpha}=[2 \alpha+3,7-2 \alpha]
$$

Dengan menggunakan definisi 2.9 operasi aritmetika pada interval, diperoleh

$$
x_{\alpha}=[5 \alpha+7,17-5 \alpha], \quad \alpha \in[0,1]
$$

Sehingga selesaian dari persamaan fuzzy $\tilde{7}+\tilde{5}=\tilde{x}$ adalah

$$
\tilde{x}=\left\{\begin{array}{cc}
0, & x \leq 7 \text { dan } x \geq 17 \\
\frac{x-7}{5}, & 7 \leq x \leq 12 \\
\frac{17-x}{5}, & 12 \leq x \leq 17
\end{array}\right.
$$

Atau dapat ditulis sebagai berikut

$$
\tilde{x}=\bigcup_{\alpha \in[0,1]} \tilde{x}_{\alpha}=\operatorname{segitiga}(x ; 7,12,17)=\widetilde{12}
$$

\section{Contoh 2:}

Cari penyelesaian persamaan fuzzy $\widetilde{15}-\tilde{5}=\tilde{x}$. Bilangan fuzzy $\tilde{5}$ dan $\widetilde{15}$ mempunyai fungsi keanggotaan

$$
\widetilde{15}=\operatorname{segitiga}(x ; 10,15,20)
$$

dan

$$
\tilde{5}=\operatorname{segitiga}(x ; 3,5,7)
$$

Dari bilangan $\widetilde{15}$ dapat dinyatakan dalam $\alpha$-cut untuk $\alpha \in[0,1]$, yaitu

$$
15_{\alpha}=[5 \alpha+10,20-5 \alpha]
$$

Dan dari bilangan $\tilde{5}$ dapat dinyatakan dalam $\alpha$ cut untuk $\alpha \in[0,1]$, yaitu

$$
5_{\alpha}=[2 \alpha+3,7-2 \alpha]
$$

Dengan menggunakan definisi 2.9 operasi aritmetika pada interval, diperoleh

$$
x_{\alpha}=[7 \alpha+3,17-7 \alpha], \quad \alpha \in[0,1]
$$

Sehingga selesaian dari persamaan fuzzy $\widetilde{15}-\tilde{5}=\tilde{x}$ adalah

$$
\tilde{x}=\left\{\begin{array}{cc}
0, & x \leq 3 \text { dan } x \geq 17 \\
\frac{x-3}{7}, & 3 \leq x \leq 10 \\
\frac{17-x}{7}, & 10 \leq x \leq 17
\end{array}\right.
$$

Atau dapat ditulis sebagai berikut

$$
\tilde{x}=\bigcup_{\alpha \in[0,1]} \tilde{x}_{\alpha}=\operatorname{segitiga}(x ; 3,10,17)=\widetilde{10}
$$

\section{Contoh 3:}

Cari penyelesaian persamaan fuzzy $\tilde{3} \cdot \tilde{2}=\tilde{x}$.

Bilangan fuzzy $\tilde{3}$ dan $\tilde{2}$ mempunyai fungsi keanggotaan

dan

$$
\tilde{3}=\operatorname{segitiga}(x ; 2,3,4)
$$

$$
\tilde{2}=\operatorname{segitiga}(x ;-1,2,5)
$$

Dari bilangan $\tilde{3}$ dapat dinyatakan dalam $\alpha$-cut untuk $\alpha \in[0,1]$, yaitu

$$
3_{\alpha}=[\alpha+2,4-\alpha]
$$

Dan dari bilangan $\tilde{2}$ dapat dinyatakan dalam $\alpha$ cut untuk $\alpha \in[0,1]$, yaitu

$$
2_{\alpha}=[3 \alpha-1,5-3 \alpha]
$$

Dengan menggunakan definisi operasi aritmetika pada interval, diperoleh

$=\left\{\begin{array}{cc}x_{\alpha} \\ {\left[3 \alpha^{2}+5 \alpha-2,3 \alpha^{2}-17 \alpha+20\right],} & \alpha \in[0.5,1]\end{array}\right.$

Sehingga selesaian dari persamaan fuzzy

$\tilde{3} \cdot \tilde{2}=\tilde{x}$ adalah

$$
\begin{aligned}
& \tilde{x}=\bigcup_{\alpha \in[0,1]} \tilde{x}_{\alpha} \\
& =\left\{\begin{array}{cc}
\frac{-13+\sqrt{121-12 x}}{-6}, & -4 \leq x \leq 0 \\
\frac{-5+\sqrt{49+12 x}}{6}, & 0 \leq x \leq 6 \\
\frac{17-\sqrt{49+12 x}}{6}, & 6 \leq x \leq 20
\end{array}\right.
\end{aligned}
$$

Contoh 4:

Cari penyelesaian persamaan fuzzy $\frac{\widetilde{1}}{\tilde{3}}=\tilde{x}$.

Bilangan fuzzy $\tilde{1}$ dan $\tilde{3}$ mempunyai fungsi keanggotaan

dan

$$
\tilde{1}=\operatorname{segitiga}(x ;-1,1,3)
$$

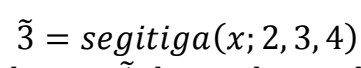

Dan dari bilangan $\tilde{1}$ dapat dinyatakan dalam $\alpha$ cut untuk $\alpha \in[0,1]$, yaitu

$$
1_{\alpha}=[2 \alpha-1,3-2 \alpha]
$$

Dari bilangan $\tilde{3}$ dapat dinyatakan dalam $\alpha$-cut untuk $\alpha \in[0,1]$, yaitu

$$
3_{\alpha}=[\alpha+2,4-\alpha]
$$

Dengan menggunakan definisi 2.9 operasi aritmetika pada interval, diperoleh

$$
x_{\alpha}= \begin{cases}{\left[\frac{2 \alpha-1}{\alpha+2}, \frac{3-2 \alpha}{\alpha+2}\right],} & \alpha \in[0,0.5] \\ {\left[\frac{2 \alpha-1}{4-\alpha}, \frac{3-2 \alpha}{\alpha+2}\right],} & \alpha \in[0.5,1]\end{cases}
$$

Sehingga selesaian dari persamaan fuzzy $\frac{\widetilde{T}}{\tilde{3}}=\tilde{x}$ adalah 


$$
\tilde{x}=\bigcup_{\alpha \in[0,1]} \tilde{x}_{\alpha}=\left\{\begin{array}{cc}
0, & x \leq-\frac{1}{2} \text { dan } x \geq \frac{3}{2} \\
\frac{2 x+1}{2-x}, & -\frac{1}{2} \leq x \leq 0 \\
\frac{4 x+1}{x+2}, & 0 \leq x \leq \frac{1}{3} \\
\frac{3-2 x}{x+2}, & \frac{1}{3} \leq x \leq \frac{3}{2}
\end{array}\right.
$$

Persamaan fuzzy terdiri dari bilangan fuzzy dan operasi aritmetika pada bilangan fuzzy. Berikut ini adalah karakterisasi sifat dari persamaan fuzzy yang sangat sederhana yaitu $\tilde{a}+\tilde{x}=\tilde{b}$ dan $\tilde{a} \cdot \tilde{x}=\tilde{b}$, dimana $\tilde{a}$ dan $\tilde{b}$ adalah bilangan fuzzy yang diketahui, dan $\tilde{x}$ adalah bilangan fuzzy yang merupakan selesaian dari persamaan fuzzy tersebut (Klir dan Yuan, 1995:114).

Misalkan diketahui bilangan fuzzy $\tilde{a} \operatorname{dan} \tilde{b}$, dan akan dicari bilangan fuzzy $\tilde{x}$. $\alpha$-cut dari $\tilde{a}, \tilde{b}$, dan $\tilde{x}$ berturut-turut adalah $a_{\alpha}=\left[a_{\alpha}^{-}, a_{\alpha}^{+}\right]$, $b_{\alpha}=\left[b_{\alpha}^{-}, b_{\alpha}^{+}\right]$, dan $x_{\alpha}=\left[x_{\alpha}^{-}, x_{\alpha}^{+}\right]$. Dari persamaan fuzzy $\tilde{a}+\tilde{x}=\tilde{b}$, dengan menggunakan $\alpha$-cut diperoleh $\left[a_{\alpha}^{-}+x_{\alpha}^{-}, a_{\alpha}^{+}+x_{\alpha}^{+}\right]=\left[b_{\alpha}^{-}, b_{\alpha}^{+}\right]$untuk $\alpha \in[0,1]$. Jadi $a_{\alpha}^{-}+x_{\alpha}^{-}=b_{\alpha}^{-}$dan $a_{\alpha}^{+}+x_{\alpha}^{+}=b_{\alpha}^{+}$, sehingga $x_{\alpha}^{-}=b_{\alpha}^{-}-a_{\alpha}^{-}$dan $x_{\alpha}^{+}=b_{\alpha}^{+}-a_{\alpha}^{+}$. Agar $\alpha$ - cut dari bilangan fuzzy $\tilde{x}$ adalah $x_{\alpha}=$ $\left[x_{\alpha}^{-}, x_{\alpha}^{+}\right]=\left[b_{\alpha}^{-}-a_{\alpha}^{-}, b_{\alpha}^{+}-a_{\alpha}^{+}\right]$, maka harus dipenuhi syarat berikut.

a. $b_{\alpha}^{-}-a_{\alpha}^{-} \leq b_{\alpha}^{+}-a_{\alpha}^{+}$untuk setiap $\alpha \in[0,1]$, dan

b. Jika $\alpha \leq \beta$, maka $b_{\alpha}^{-}-a_{\alpha}^{-} \leq b_{\beta}^{-}-a_{\beta}^{-} \leq b_{\beta}^{+}-$ $a_{\beta}^{+} \leq b_{\alpha}^{+}-a_{\alpha}^{+}$.

Jika kedua syarat tersebut dipenuhi, maka selesaian persamaan fuzzy $\tilde{a}+\tilde{x}=\tilde{b}$ yaitu

$$
\tilde{x}=\bigcup_{\alpha \in[0,1]} \tilde{x}_{\alpha}
$$

Dan untuk persamaan fuzzy $\tilde{a} \cdot \tilde{x}=\tilde{b}$ dimana $\tilde{a}$ dan $\tilde{b}$ adalah bilangan fuzzy pada $R^{+}$, maka solusi dari persamaan fuzzy harus memenuhi syarat berikut.

a. $b_{\alpha}^{-} / a_{\alpha}^{-} \leq b_{\alpha}^{+} / a_{\alpha}^{+}$untuk $\alpha \in[0,1]$, dan

b. Jika $\alpha \leq \beta$, maka $b_{\alpha}^{-} / a_{\alpha}^{-} \leq b_{\beta}^{-} / a_{\beta}^{-} \leq b_{\beta}^{+} / a_{\beta}^{+} \leq$ $b_{\alpha}^{+} / a_{\alpha}^{+}$.

Jika kedua syarat tersebut terpenuhi, maka selesaian dari persamaan fuzzy $\tilde{a} \cdot \tilde{x}=\tilde{b}$ yaitu

$$
\tilde{x}=\bigcup_{\alpha \in[0,1]} \tilde{x}_{\alpha}
$$

(Klir dan Yuan, 1995:115-116).

\section{Contoh 5:}

Misalkan diberikan persamaan fuzzy

$$
\frac{\tilde{4} \cdot \tilde{x}+\tilde{8}}{\tilde{5}}-\tilde{1}=\tilde{3}
$$

dengan bilangan fuzzy

$$
\begin{gathered}
\tilde{1}=\operatorname{segitiga}(0,1,2) \\
\tilde{3}=\operatorname{segitiga}(-1,3,7) \\
\tilde{4}=\operatorname{segitiga}(3,4,5)
\end{gathered}
$$

$$
\begin{gathered}
\tilde{5}=\operatorname{segitiga}(4,5,6) \\
\tilde{8}=\operatorname{segitiga}(6,8,10)
\end{gathered}
$$

representasi $\tilde{1}, \tilde{3}, \tilde{4}, \tilde{5}$, dan $\tilde{8}$ yaitu $1_{\alpha}=[\alpha, 2-\alpha]$, $3_{\alpha}=[4 \alpha-1,7-4 \alpha] \quad, \quad 4_{\alpha}=[\alpha+3,5-\alpha]$, $5_{\alpha}=[\alpha+4,6-\alpha]$, dan $8_{\alpha}=[2 \alpha+6,10-2 \alpha]$. Dari persamaan fuzzy

Misal:

$$
\frac{\tilde{4} \cdot \tilde{x}+\tilde{8}}{\tilde{5}}-\tilde{1}=\tilde{3}
$$

$$
\begin{gathered}
\frac{\tilde{4} \cdot \tilde{x}+\tilde{8}}{\tilde{5}}=\tilde{r} \\
\tilde{4} \cdot \tilde{x}+\tilde{8}=\tilde{s} \\
\tilde{4} \cdot \tilde{x}=\tilde{t}
\end{gathered}
$$

Maka,

$$
\begin{gathered}
\tilde{r}-\tilde{1}=\tilde{3} \\
\tilde{s} \\
\tilde{\tilde{5}}=\tilde{r} \\
\tilde{t}+\tilde{8}=\tilde{s} \\
\tilde{4} \cdot \tilde{x}=\tilde{t}
\end{gathered}
$$

Untuk persamaan 3.1, dengan menggunakan $\alpha$ cut diperoleh $\left[r_{\alpha}^{-}-(2-\alpha), r_{\alpha}^{+}-\alpha\right]=$ $[4 \alpha-1,7-4 \alpha]$ untuk $\alpha \in[0,1]$. Jadi $r_{\alpha}^{-}-$ $(2-\alpha)=4 \alpha-1$ dan $r_{\alpha}^{+}-\alpha=7-4 \alpha$. Sehingga

$$
\begin{aligned}
& r_{\alpha}^{-}=3 \alpha+1 \\
& r_{\alpha}^{+}=7-3 \alpha
\end{aligned}
$$

Kemudian diuji bahwa $r_{\alpha}^{-} \leq r_{\alpha}^{+}$dan jika $0 \leq \alpha \leq \beta \leq 1$ maka $3 \alpha+1 \leq 3 \beta+1 \leq 7-$ $3 \beta \leq 7-3 \alpha$, agar $\alpha$-cut dari bilangan fuzzy $\tilde{r}$ adalah $r_{\alpha}=\left[r_{\alpha}^{-}, r_{\alpha}^{+}\right]$.

Sehingga

$$
r_{\alpha}=[3 \alpha+1,7-3 \alpha]
$$

untuk setiap $\alpha \in[0,1]$. Sehingga selesaian dari persamaan fuzzy $\tilde{r}-\tilde{1}=\tilde{3}$ adalah

$$
\tilde{r}=\bigcup_{\alpha \in[0,1]} \tilde{r}_{\alpha}=\left\{\begin{array}{cc}
0, & x \leq 1 \text { dan } x \geq 7 \\
\frac{x-1}{3}, & 1 \leq x \leq 4 \\
\frac{7-x}{3}, & 4 \leq x \leq 7
\end{array}\right.
$$

Karena $\tilde{r}=\tilde{4}$, maka persamaan 3.2 menjadi $\frac{\tilde{s}}{\tilde{5}}=$ 4. Dari persamaan $\frac{\tilde{s}}{\tilde{5}}=\tilde{4}$ dengan menggunakan $\alpha$ cut diperoleh $\left[\frac{s_{\alpha}^{-}}{6-\alpha}, \frac{s_{\alpha}^{+}}{\alpha+4}\right]=[3 \alpha+1,7-3 \alpha]$ untuk $\alpha \in[0,1]$. Jadi $\frac{s_{\alpha}^{\bar{\alpha}}}{6-\alpha}=3 \alpha+1$ dan $\frac{s_{\alpha}^{+}}{\alpha+4}=7-3 \alpha$. Sehingga

$$
\begin{aligned}
& s_{\alpha}^{-}=-3 \alpha^{2}+17 \alpha+6 \\
& s_{\alpha}^{+}=-3 \alpha^{2}-5 \alpha+28
\end{aligned}
$$

Kemudian diuji bahwa $s_{\alpha}^{-} \leq s_{\alpha}^{+}$dan jika $0 \leq \alpha \leq \beta \leq 1$ maka $-3 \alpha^{2}+17 \alpha+6 \leq-3 \beta^{2}+$ $17 \beta+6 \leq-3 \beta^{2}-5 \beta+28 \leq-3 \alpha^{2}-5 \alpha+28$, agar $\alpha$ - cut dari bilangan fuzzy $\tilde{s}$ adalah $s_{\alpha}=\left[s_{\alpha}^{-}, s_{\alpha}^{+}\right]$.

Sehingga

$$
s_{\alpha}=\left[-3 \alpha^{2}+17 \alpha+6,-3 \alpha^{2}-5 \alpha+28\right]
$$

untuk setiap $\alpha \in[0,1]$. Sehingga selesaian dari persamaan fuzzy $\frac{\tilde{s}}{\tilde{5}}=\tilde{4}$ adalah 


$$
\begin{aligned}
& \tilde{s}=\bigcup_{\alpha \in[0,1]} \tilde{s}_{\alpha} \\
& =\left\{\begin{array}{cc}
\frac{-17+\sqrt{361-12 x}}{-6}, & 6 \leq x \leq 20 \\
\frac{5-\sqrt{361-12 x}}{-6}, & 20 \leq x \leq 28
\end{array}\right.
\end{aligned}
$$

Karena $\tilde{s}=\widetilde{20}$, maka persamaan 3.3 menjadi $\tilde{t}+\tilde{8}=\widetilde{20}$. Dari persamaan $\tilde{t}+\tilde{8}=\widetilde{20}$ dengan menggunakan $\alpha$ - cut diperoleh $\left[t_{\alpha}^{-}+(2 \alpha+\right.$ $\left.6), t_{\alpha}^{+}+(10-2 \alpha)\right]=\left[-3 \alpha^{2}+17 \alpha+6,-3 \alpha^{2}-\right.$ $5 \alpha+28]$ untuk $\alpha \in[0,1]$. Jadi $t_{\alpha}^{-}+(2 \alpha+6)=$ $-3 \alpha^{2}+17 \alpha+6$ dan $t_{\alpha}^{+}+(10-2 \alpha)=-3 \alpha^{2}-$ $5 \alpha+28$. Sehingga

$$
\begin{gathered}
t_{\alpha}^{-}=-3 \alpha^{2}+15 \alpha \\
t_{\alpha}^{+}=-3 \alpha^{2}-3 \alpha+18
\end{gathered}
$$

Kemudian diuji bahwa $t_{\alpha}^{-} \leq t_{\alpha}^{+}$dan jika $0 \leq \alpha \leq \beta \leq 1$ maka $-3 \alpha^{2}+15 \alpha \leq-3 \beta^{2}+$ $15 \beta \leq-3 \beta^{2}-3 \beta+18 \leq-3 \alpha^{2}-3 \alpha+18$, agar $\alpha$-cut dari bilangan fuzzy $\tilde{t}$ adalah $t_{\alpha}=\left[t_{\alpha}^{-}, t_{\alpha}^{+}\right]$. Sehingga

$$
t_{\alpha}=\left[-3 \alpha^{2}+15 \alpha,-3 \alpha^{2}-3 \alpha+18\right]
$$

untuk setiap $\alpha \in[0,1]$. Sehingga selesaian dari persamaan fuzzy $\tilde{t}+\widetilde{8}=\widetilde{20}$ adalah

$$
\begin{aligned}
& \tilde{t}=\bigcup_{\alpha \in[0,1]} \tilde{t}_{\alpha} \\
& =\left\{\begin{array}{cc}
\frac{-15+\sqrt{225-12 x}}{-6}, & 0 \leq x \leq 12 \\
\frac{3-\sqrt{225-12 x}}{-6}, & 12 \leq x \leq 18
\end{array}\right.
\end{aligned}
$$

Karena $\tilde{t}=\widetilde{12}$, maka persamaan 3.4 menjadi $\tilde{4} \cdot \tilde{x}=\widetilde{12}$. Dari persamaan $\tilde{4} \cdot \tilde{x}=\widetilde{12}$ dengan menggunakan $\alpha$ - cut diperoleh $[(\alpha+3)$. $\left.x_{\alpha}^{-},(5-\alpha) \cdot x_{\alpha}^{+}\right]=\left[-3 \alpha^{2}+15 \alpha,-3 \alpha^{2}-3 \alpha+\right.$

18] untuk $\alpha \in[0,1]$. Jadi $(\alpha+3) \cdot x_{\alpha}^{-}=-3 \alpha^{2}+$ $15 \alpha$ dan $(5-\alpha) \cdot x_{\alpha}^{+}=-3 \alpha^{2}-3 \alpha+18$. Sehingga

$$
\begin{gathered}
x_{\alpha}^{-}=\frac{-3 \alpha^{2}+15 \alpha}{\alpha+3} \\
x_{\alpha}^{+}=\frac{-3 \alpha^{2}-3 \alpha+18}{5-\alpha}
\end{gathered}
$$

Kemudian diuji bahwa $x_{\alpha}^{-} \leq x_{\alpha}^{+}$dan jika $0 \leq \alpha \leq \beta \leq 1$ maka $\frac{-3 \alpha^{2}+15 \alpha}{\alpha+3} \leq \frac{-3 \beta^{2}+15 \beta}{\beta+3} \leq$ $\frac{-3 \beta^{2}-3 \beta+18}{5-\beta} \leq \frac{-3 \alpha^{2}-3 \alpha+18}{5-\alpha}$, agar $\alpha$-cut dari bilangan fuzzy $\tilde{x}$ adalah $x_{\alpha}=\left[x_{\alpha}^{-}, x_{\alpha}^{+}\right]$.

Sehingga

$$
x_{\alpha}=\left[\frac{-3 \alpha^{2}+15 \alpha}{\alpha+3}, \frac{-3 \alpha^{2}-3 \alpha+18}{5-\alpha}\right]
$$

untuk setiap $\alpha \in[0,1]$. Sehingga selesaian dari persamaan

$\frac{\tilde{4} \cdot \tilde{x}+\widetilde{8}}{\tilde{5}}-\tilde{1}=\tilde{3}$ adalah

$$
\begin{aligned}
& \tilde{x}=\bigcup_{\alpha \in[0,1]} \tilde{x}_{\alpha} \\
& =\left\{\begin{array}{cc}
0, & x \leq 0 \text { dan } x \geq \frac{18}{5} \\
\frac{x-15+\sqrt{x^{2}-66 x+225}}{-6}, & 0 \leq x \leq 3 \\
\frac{-6-x-\sqrt{x^{2}-66 x+225}}{-6}, & 3 \leq x \leq \frac{18}{5}
\end{array}\right.
\end{aligned}
$$

\section{PENUTUP}

\section{Kesimpulan}

Persamaan fuzzy adalah kombinasi dari bilangan fuzzy dan operasi aritmetika pada bilangan fuzzy. Bilangan fuzzy merupakan konsep perluasan dari bilangan tegas yang memenuhi empat sifat diantaranya yaitu: himpunan fuzzy normal, mempunyai support yang terbatas, semua $\alpha$-cut merupakan interval tertutup untuk semua $\alpha \in[0,1]$, dan konvek. Dan operasi aritmetika dasar pada bilangan fuzzy merupakan konsep perluasan dari operasi aritmetika dasar pada umumnya, yaitu dengan mengikutsertakan derajat keanggotaannya.

Prosedur penyelesaian persamaan fuzzy yaitu dengan merepresentasikan bilangan fuzzy dalam bentuk $\alpha$ - cut menggunakan fungsi keanggotaan segitiga. Kemudian mengoperasikannya menggunakan operasi aritmetika dasar pada bilangan fuzzy. Penentuan hasil operasi aritmetika pada persamaan fuzzy dilakukan dengan merepresentasikan ulang bilangan fuzzy tersebut dengan $\alpha$-cut, sehingga didapatkan bilangan fuzzy baru sebagai hasil penyelesaian dari persamaan fuzzy.

\section{Saran}

Pada skripsi ini, penulis hanya membahas pada persamaan fuzzy. Maka dari itu, penulis menyarankan kepada pembaca untuk mengkaji bentuk aljabar klasik yang lainnya, yaitu tentang pertidaksamaan linier yang dikembangkan menjadi pertaksamaan fuzzy. Dapat juga mengkaji lebih lanjut tentang sistem persamaan fuzzy.

\section{DAFTAR PUSTAKA}

[1] Anton, Howard. 2000. Dasar-Dasar Aljabar Linier. Batam: Interaksara.

[2] Ayres, Frank dan Schmidt, Philip A. 2004. Schaum's Outline of Theory and Problem's of College Mathematics. Terjemahan Alit Bondan. Jakarta: Erlangga.

[3] Chen, Guanrong dan Pham, Trung Tat. 2000. Introduction to Fuzzy Sets, Fuzzy Logic, and Fuzzy Control Systems. London: CRC Press. 
[4] Dubbois, Deider dan Prade, Henri. 1980. Fuzzy Sets and Systems, Theory and Applications. New York: Academic Press.

[5] Klir, George J. dan Yuan, Bo. 1995. Fuzzy Set and Fuzzy Logic: Theory and Applications. New Jersey: Prentice Hall International, INC.

[6] Kusumadewi, Sri. 2002. Analisis dan Desain System Fuzzy Menggunakan Toolbox Matlab. Yogyakarta: Graha Ilmu.

[7] Kusumadewi, Sri dan Purnomo, Hari. 2004. Aplikasi Logika Fuzzy untuk Pendukung Keputusan. Yogyakarta: Graha Ilmu.

[8] Sivanandam, Sumathi dan Deepa. 2006. Introduction to Fuzzy Logic Using Matlab. India: Springer.

[9] Susilo, Frans. 2006. Himpunan dan Logika Kabur serta Aplikasinya. Yogyakarta: Graha Ilmu.
[10] Utomo, Tri. 2012. Operasi Aritmetika Dasar pada Bilangan Fuzzy dan Sifat-Sifatnya. Skripsi. Universitas Islam Negeri Maulana Malik Ibrahim Malang.

[11] Yudha D, Made. No. 36 Pebruari 1997. Sistem Fuzzy: Sebuah Kecenderungan. Science. Hal: 8-9.

[12] Zadeh, Lotfi A. 2000. Fuzzy Sets and fuzzy Information-Granulation Theory. Beijing: Beijing Normal University Press.

[13] Zhang, Huaguang dan Liu, Derong. 2006. Interval Type-2 Fuzzy Hidden Markov Models. Hungary: Proc. of IEEE FUZZ Conference, Budapest 